NEWS AND NOTES / NOUVELLES ET NOTES

Compiled by Teresa Lee

Canadian Association of Research Libraries (CARL) news release - Research library spending on electronic serials surpasses print serials for the second consecutive year

National Network of Libraries for Health (NNLH) Concept of Operations released

Canadian Standards Association and Canada Health Infoway team up for the advancement of International Health Information Technology Standards

British Library-led partnership chosen to run UK PubMed Central: UK to launch online research archive to further biomedical discovery

Release of the new WorldCat.org Web site

Google allows downloading of the classics

Google Health Co-op call for health librarians

NLM Long Range Plan 2006-2016

NIH MedlinePlus magazine launched

MEDLINE turns 35!

CHLA / ABSC Annual Conference 2007 - Capitalizing on health partnerships

Canadian Library Association (CLA) 2007 Annual Conference: Retain - recruit - restructure: regenerating the library community

Medical Library Association (MLA) 2007 Annual Conference - Information revolution: change is in the air

Special Libraries Association (SLA) 2007 Annual Conference

American Library Association (ALA) Midwinter Meeting 2007

Association of College \& Research Libraries (ACRL) 2007 Annual Conference -

Sailing into the future: charting our destiny

First International Public Knowledge Project (PKP) Scholarly Publishing Conference: preliminary announcement

The 4th International Conference on Evidence-based Library \& Information Practice

The 5th Canadian Cochrane Symposium

Northern Exposure to Leadership Institute 2007

FIS Professional Learning Centre - Measuring Customer Satisfaction in Information Services 


\section{NEWS AND NOTES / NOUVELLES ET NOTES}

\section{Canadian Association of Research Libraries (CARL) news release - Research library spending on electronic serials surpasses print serials for the second consecutive year}

http://www.carl-abrc.ca/projects/statistics/pdf/stats_media_release-2006-e.pdf

Spending on electronic serials by Canada's research libraries in 2004-2005 rose to just over \$94 million, a $20 \%$ increase over 2003-2004, compared to a decrease of 3\% on print serials expenditures to $\$ 69.6$ million. For the second consecutive year, electronic serials expenditures have exceeded print serials expenditures.

\section{National Network of Libraries for Health (NNLH) Concept of Operations released}

http://chla-absc.ca/nnlh/indexe.htm

Over the past 12 months, members of the Canadian Health Libraries / Association des bibliothèques de la santé du Canada (CHLA / ABSC) Board and the NNLH Task Force have worked with a consultant to develop a Concept of Operations for the National Network. View the complete document at http://chla-absc.ca/nnlh/coo.pdf.

\section{Canadian Standards Association and Canada Health Infoway team up for the advancement of International Health Information Technology Standards}

http://www.infoway-inforoute.ca/en/News-Events/InTheNews_long.aspx?UID=239

Canada Health Infoway and the Canadian Standards Association (CSA) signed a memorandum of understanding to work together for the advancement of health information technology standards. These health information standards are critical to helping ensure that authorized health care providers can electronically share a patient's medical information to provide better health care services. 


\section{British Library-led partnership chosen to run UK PubMed Central: UK to launch online research archive to further biomedical discovery}

http://www.bl.uk/news/2006/pressrelease20060731a.html

UK Scientists will be able to access a vast collection of biomedical research at the touch of a button thanks to a major new initiative that aims to promote the free transfer of ideas in a bid to speed up scientific discovery. Based on a model currently used in the United States, UK PubMed Central (UKPMC) will provide free access to an online digital archive of peerreviewed research papers in the medical and life sciences. The Wellcome Trust, as part of a nine-strong group of UK research funders, announced that the contract to run UKPMC has been awarded to a partnership between the British Library, The University of Manchester, and the European Bioinformatics Institute (EBI).

\section{Release of the new WorldCat.org Web site}

OCLC has released the new WorldCat.org Web site. This site (and a downloadable WorldCat search box you can easily add to your Web site) opens the complete WorldCat database to the public, not just the smaller data subsets utilized by Open WorldCat partner sites such as Google, Yahoo! Search, and others. WorldCat.org builds on the success of OCLC's Open WorldCat Program, which has elevated the visibility of library materials on the open Web since the summer of 2003. The new site is available at http://www.worldcat.org/\#.

\section{Google allows downloading of the classics}

http://googleblog.blogspot.com/2006/08/download-classics.html

Starting on 30 August 2006, you can go to Google Book Search and download full copies of out-of-copyright books to read at your own pace. You're free to choose from a diverse collection of public domain titles - from well-known classics to obscure gems. 


\section{Google Health Co-op call for health librarians}

Google recently enlisted Howard Fuller of Stanford Library to lead a team of health librarians in the Google Health project. Volunteer librarians will tag online health content for quality. For a blog discussion on this topic, see the University of British Columbia Google Scholar Blog at http://weblogs.elearning.ubc.ca/googlescholar/archives/030461.html.

\section{NLM Long Range Plan 2006-2016}

http://www.nlm.nih.gov/pubs/plan/lrp06/lrp06_home.html

The NLM Board of Regents approved Charting the Course for the 21st Century: NLM's Long Range Plan 2006-2016 on 19 September 2006.

\section{NIH MedlinePlus magazine launched}

http://nnlm.gov/pnr/dragonfly/2006/05/11/medlineplus-magazine/

Stating that consumers can now have access to "information that comes directly from the world's leading medical and health research organization", the Honorable Paul Rogers, former member of Congress and Chairman of The Friends of the National Library of Medicine, announced the launch of NIH MedlinePlus magazine. This quarterly publication will be distributed free of charge to patients and their families in the waiting rooms of selected practicing physicians across the nation. The magazine is available at http://www.nlm.nih.gov/medlineplus/magazine.html.

\section{MEDLINE turns 35!}

http://www.nlm.nih.gov/pubs/techbull/so06/so06_med_35.html

October 2006 marks the 35th anniversary of MEDLINE (MEDLARS® Online). 


\section{Meetings, conferences and workshops}

\section{CHLA / ABSC Annual Conference 2007 - Capitalizing on health partnerships}

The 2007 CHLA / ABSC Annual Conference will take place in Ottawa, Ontario, 28 May - 1 June. The deadline for abstracts for contributed papers and posters is 15 December 2006. Further details on the program and registration will be posted on the conference Web site at http://www.chla-absc.ca/2007/index_e.htm. Contact information is available at chla-absc2007.cisti@nrc-cnrc.gc.ca.

\section{Canadian Library Association (CLA) 2007 Annual Conference: Retain - recruit - restructure: regenerating the library community}

The CLA's annual conference will take place in St. John's, Newfoundland, 23-27 May 2007. For details, check the conference Web site at http://www.cla.ca.

\section{Medical Library Association (MLA) 2007 Annual Conference - Information revolution: change is in the air}

The MLA's annual meeting will take place 18-23 May 2007, in Philadelphia, Pennsylvania. For details, check the conference Web site at http://www.mlanet.org. 


\section{Special Libraries Association (SLA) 2007 Annual Conference}

The SLA will hold its annual conference in Denver, Colorado, 3-6 June 2007. For details, check the conference Web site at http://www.sla.org.

\section{American Library Association (ALA) Midwinter Meeting 2007}

The ALA's 2007 Midwinter Meeting will be held in Seattle, Washington, 19-24 January. For details, check the conference Web site at http://www.ala.org/ala/eventsandconferencesb/midwinter/2007/home.htm.

\section{Association of College \& Research Libraries (ACRL) 2007 Annual Conference - Sailing into the future: charting our destiny}

The annual meeting of ACRL will take place 29 March - 1 April 2007, in Baltimore, Maryland. The conference is open for registration, and full details are available at http://www.acrl.org/ala/acrl/acrlevents/baltimore/baltimore.htm. 


\section{First International Public Knowledge Project (PKP) Scholarly Publishing Conference: preliminary announcement}

The Public Knowledge Project is pleased to announce that the first international PKP conference will be held 11-13 July 2007 in Vancouver, British Columbia, Canada. The conference will promote and celebrate the quality use of the PKP open source software suite: Open Journal Systems (OJS), Open Conference Systems (OCS), and the Open Archives Harvester. For details, check the conference Web site at http://pkp.sfu.ca/.

\section{The 4th International Conference on Evidence-based Library \& Information Practice}

The 4th Evidence Based Library and Information Practice Conference (EBLIP4) will be held 6-9 May 2007, in Chapel Hill, North Carolina. The meeting will be followed by 2 days of CE. Additional info may be found at www.eblip4.unc.edu.

\section{The 5th Canadian Cochrane Symposium}

The Canadian Cochrane Network and Centre will hold its 5th Symposium in Ottawa, Ontario, 12-13 February 2007. The theme of the symposium is "Knowledge for Health". For further information, check the conference Web site at www.cochrane.uottawa.ca/symposia.asp. 


\section{Professional development}

\section{Northern Exposure to Leadership Institute 2007}

The ninth Northern Exposure to Leadership Institute (NELI) will be held in Emerald Lake, British Columbia, 1-6 March 2007. For more information, see http://www.ls.ualberta.ca/neli/index.html.

\section{FIS Professional Learning Centre - Measuring Customer Satisfaction in Information Services}

This 2-day workshop, scheduled for 1-2 February 2007, aims to provide participants with a framework for measuring customer satisfaction and service quality in a library or information services setting. For more information, see http://plc.fis.utoronto.ca.

\section{FIS Professional Learning Centre - Usability Evaluation}

In this 8-week workshop, scheduled for 19 March 2007 - 7 May 2007, participants will learn to prepare, conduct, and report on the results of usability assessments. For more information, see http://plc.fis.utoronto.ca. 